\title{
THE USE OF ANTIMICROBIAL PHOTODYNAMIC THERAPY MEDIATED BY MC540 IN THE INFECTED WOUND MODEL
}

Shmigol TA ${ }^{1 凶}$, Sobianin $\mathrm{KA}^{2}$, Prusak-Glotov MV1 , Shchelykalina SP${ }^{3}$, Nevezhin EV ${ }^{3}$, Yermolaeva SA ${ }^{4}$, Negrebetsky VadV

${ }^{1}$ Department of Medicinal Chemistry and Toxicology, Pirogov Russian National Research Medical University, Moscow

${ }^{2}$ Laboratory of Biological Research. Institute for Translational Medicine, Pirogov Russian National Research Medical University, Moscow

${ }^{3}$ Department of Medical Cybernetics and Informatics, Biomedical Faculty, Pirogov Russian National Research Medical University, Moscow

${ }^{4}$ Laboratory for the Ecology of Pathogens, Gamaleya Federal Research Center for Epidemiology and Microbiology, Moscow

Photodynamic therapy (PDT) is an alternative to conventional therapies of infections. It can kill drug-resistant bacteria without damaging host tissues. In the present work we use the multiresistant strain PA21 of Pseudomonas aeruginosa to model a wound infection in mice and study the effect of PTD mediated by aqueous solutions of the anionic photosensitizer merocyanine 540 (solubilized in water and in $0.25 \mathrm{M}$ sodium chloride) on bacterial decontamination and wound healing. To assess a therapeutic effect of PDT, we monitored bacterial contamination of the wound, measured the wound size in two planes using a caliper and carried out a histopathological examination of infected tissue sections. Our study reveals that PDT mediated by MC540 in the sodium chloride solution can induce bacterial death, inhibit bacterial re-growth and accelerate wound healing.

Keywords: antimicrobial photodynamic therapy, multiresistant clinical strain, Pseudomonas aeruginosa, skin infection, soft tissue infection, wound healing, merocyanine 540, wound infection

Funding: this study was supported by the Russian Foundation for Basic Research (Project ID 16-33-00970 mol_a).

$\triangle$ Correspondence should be addressed: Tatiana Shmigol

Ostrovityanova 1, Moscow, 117997; tatishtish@gmail.com

Received: 20.01.2018 Accepted: 23.03.2018

DOI: $10.24075 /$ brsmu.2018.011

\section{ПРИМЕНЕНИЕ АНТИМИКРОБНОЙ ФОТОДИНАМИЧЕСКОЙ ТЕРАПИИ НА ОСНОВЕ МЦ540 К МОДЕЛИ РАНЕВОЙ ИНФЕКЦИИ}

Т. А. Шмиголь ${ }^{\natural}$, К. А. Собянин ${ }^{2}$ М. В. Прусак-Глотов ${ }^{1}$, С. П. Щелыкалина ${ }^{3}$, Е. В. Невежин ${ }^{3}$, С. А. Ермолаева

В. В. Негребецкий

${ }^{1}$ Отдел медицинской химии и токсикологии, Российский национальный исследовательский медицинский университет имени Н. И. Пирогова, Москва

2 Лаборатория биологических испытаний, Институт трансляционной медицины, Российский национальный исследовательский медицинский университет имени Н. И. Пирогова, Москва

Кафедра медицинской кибернетики и информатики, медико-биологический факультет, Российский национальный исследовательский медицинский университет имени Н. И. Пирогова, Москва

4 Лаборатория экологии возбудителей инфекций, Национальный исследовательский центр эпидемиологии и микробиологии имени Н. Ф. Гамалеи, Москва

Фотодинамическая терапия (ФДТ) является альтернативным методом лечения инфекций, позволяющим убивать лекарственно-устойчивые бактерии без повреждения ткани хозяина. В настоящем исследовании использован полирезистентный клинический штамм Pseudomonas aeruginosa PA21 (P. aeruginosa) в модели раневой инфекции на мышах для изучения влияния ФДТ (в водных растворах анионного фотосенсибилизатора Мероцианина 540 (МЦ540): в воде и 0,25 M NaCl) на бактериальную инактивацию и заживление ран. После проведения ФДТ гибель бактерий оценивали путем определения бактериологической нагрузки в ранах, процесс заживления ран контролировали прямым измерением штангенциркулем в двух проекциях, а также проведением патоморфологических исследований послойных срезов инфицированных ран. Полученные результаты показали, что ФДТ в присутствии МЦ540 в растворе хлорида натрия (но не МЦ540 в воде) способна вызывать гибель бактерии, препятствовать их восстановлению и значительно ускорять процесс заживления ран.

Ключевые слова: антимикробная фотодинамическая терапия, полирезистентный клинический штамм Pseudomonas aeruginosa, инфекция кожи и мягких тканей, заживление ран, мероцианин 540, раневая инфекция

Финансирование: исследование выполнено при финансовой поддержке РФФИ в рамках научного проекта № 16-33-00970 мол_а.

$\bigotimes$ Для корреспонденции: Татьяна Анатольевна Шмиголь

ул. Островитянова, д. 1, г. Москва, 117997; tatishtish@gmail.com

Статья получена: 20.01.2018 Статья принята к печати: 23.03.2018

DOI: 10.24075 /vrgmu.2018.011

Skin is the body's natural physical barrier and the first line of defense against pathogens. Damaged skin can end up getting infected. In turn, infection can delay wound healing, compromise a person's general health and even increase the risk of death. Antibiotics once revolutionized the therapy of infections, but today the growing incidence of resistant bacteria compels the search for new alternatives to the conventional management of localized infections. One of the promising solutions here is photodynamic therapy (PDT) that is normally used in cancer treatment [1-3] but has been recently proposed to combat bacterial infections [4-7]. Antimicrobial PDT relies on the use of photosensitizers (PS), non-toxic dyes that can be activated 
by a specific wavelength of light. The PS is introduced into the infected wound that is subsequently exposed to a source of monochromatic light with a required wavelength [8-9]. Once activated, PS starts producing free radicals and/or singlet oxygen that are lethal for pathogens.

The aim of this study was to investigate the effect of MC540mediated PDT on bacterial growth in the wound and wound healing in a murine model. BALB/c mice were infected with the multidrug resistant clinical strain PA21 of Pseudomonas aeruginosa. To assess a therapeutic effect of PDT, we monitored bacterial contamination of the wound, measured the wound size in two planes using a caliper and carried out a histopathological examination of infected tissue sections.

\section{METHODS}

\section{Photosensitizer}

The stock solution of $1 \times 10^{-3} \mathrm{M}$ anionic dye merocyanine 540 (Sigma-Aldrich, Switzerland) was prepared in 96\% ethanol on the day of the experiment. MC540 concentrations were determined spectrophotometrically based on the extinction coefficient of MC540 in water $\varepsilon_{500}=63000 \mathrm{M}^{-1} \mathrm{~cm}^{-1}$. The stock solution was diluted with water or $0.25 \mathrm{M}$ sodium chloride solution (ACROS, USA) to reach working MC540 concentrations of $25 \mu \mathrm{M}$.

\section{Bacterial culture}

The multiresistant strain PA21 of Pseudomonas aeruginosa used in our study was obtained from a collection of Gamaleya Federal Research Center for Epidemiology and Microbiology.

$P$. aeruginosa cells were incubated overnight at $37^{\circ} \mathrm{C}$ in the Brain Heart Infusion broth (BHI Difco, USA), diluted 100-fold in the fresh medium, and grown until they reached the optical density $O D_{600}$ of 1 , which corresponds to the concentration of $10^{9} \mathrm{CFU} / \mathrm{ml}$. The culture was washed twice in PBS $(\mathrm{pH}=7.4)$ (Ecoservice, Russia) and applied onto the wound in $50 \mu \mathrm{l}$ aliquots.

\section{Bacterial burden in the wounds}

Swabs were taken from wound surfaces using cotton balls. Then the balls were placed into the test tube containing $0.9 \mathrm{ml}$ normal saline, which was subsequently used to prepare a series of dilutions: 1:10, 1:100, and 1:1000. Each dilution was seeded onto two dishes treated with agarized media (BHI Difco, USA). Twenty-four hours later, the colonies were harvested and counted; the counts were converted to log CFU/ml.

\section{Antimicrobial photodynamic therapy}

All manipulations were performed using aseptic techniques and gentle anesthesia. The experiments were carried out

Table 1. Study design

\begin{tabular}{|l|c|c|c|}
\hline \multicolumn{1}{|c|}{ Group } & Number of animals & Bacteria & Treatment \\
\hline Group A: absolute control & 18 & $P$. aeruginosa & No treatment \\
\hline Group B: light control & 18 & $P$. aeruginosa & Light $\left(6 \mathrm{~J} / \mathrm{cm}^{2} ; \lambda=530 \mathrm{~nm}\right)$ \\
\hline Group C: PDT + MC540 & 18 & $P$. aeruginosa & MC540+light $\left(6 \mathrm{~J} / \mathrm{cm}^{2} ; \lambda=530 \mathrm{~nm}\right)$ \\
\hline Group D: PDT + MC540+ $0.25 \mathrm{M} \mathrm{NaCl}$ & 18 & $P$. aeruginosa & MC540_0.25 M NaCl $+\operatorname{light}\left(6 \mathrm{~J} / \mathrm{cm}^{2} ; \lambda=530 \mathrm{~nm}\right)$ \\
\hline
\end{tabular}

in compliance with the principles of bioethics, international guidelines of the European Convention for the Protection of Vertebrate Animals (Strasbourg, March 1986) and the Declaration of Helsinki.

The experiments were conducted in 6-8 weeks old BALB/c mice weighing 17 to $21 \mathrm{~g}$. Twenty-four hours before PDT we shaved the fur from a $2-\mathrm{cm}^{2}$ area on animals' backs and outlined the wound contours with a permanent marker. Before the surgery, the animals were anesthetized with inhaled isoflurane. The surgical site was cleansed with an antiseptic agent twice. The excised wound was $1.5 \mathrm{~cm}$ in diameter and extended through the skin, subcutaneous tissue and fascia down to the muscle. The wound was inoculated with a $50 \mu \mathrm{l}$ aliquot of $10^{7} \mathrm{CFU} / \mathrm{ml} P$. aeruginosa suspension. Six hours after wound modeling the mice received photodynamic therapy.

The animals were divided into 4 groups (Table 1). Mice from group A ( $n=18$ ) were used as absolute control (no treatment); mice from group $\mathrm{B}(n=18)$ were used as light control (irradiation with $530 \mathrm{~nm}$ monochromatic light for $5 \mathrm{~min}$ ); mice from group $\mathrm{C}$ $(n=18)$ received PDT mediated by $25 \mu \mathrm{M}$ aqueous solution of MC540 (irradiation with $530 \mathrm{~nm}$ monochromatic light for $5 \mathrm{~min}$ ); mice from group $\mathrm{D}(n=18)$ received PDT mediated by $25 \mu \mathrm{M}$ aqueous solution of MC540 containing 0.25 M sodium chloride (irradiation with $530 \mathrm{~nm}$ monochromatic light for $5 \mathrm{~min}$ ). Three animals were selected from each group to study the long-term effects of treatment (36 days).

The wounds were treated with $50 \mu \mathrm{l}$ of $25 \mu \mathrm{M}$ aqueous solution of MC540 containing $0.25 \mathrm{M} \mathrm{NaCl}$ and then exposed for $5 \mathrm{~min}$ to a source of monochromatic light with a $530 \mathrm{~nm}$ wavelength and a power density of $2 \mathrm{~mW} / \mathrm{cm}^{2}$, which ensured the total dose of $6 \mathrm{~J} / \mathrm{cm}^{2}$.

\section{Histological analysis}

The samples were fixed in 10\% buffered formalin and embedded in paraffin. The paraffin-embedded 2-7 $\mu$ m-thick sections were stained with hematoxylin-eosin and subjected to microstructural and morphometric analyses. Morphometric evaluation was performed using the AxioimagerA-2 microscope (Carl Zeiss, Germany).

\section{Wound healing}

While monitoring the condition of the wounds, we noted the signs of inflammation, type and quantity of wound drainage, etc. Wound sizes were measured with a ruler and a caliper in two planes 1 hour before PDT on days 2, 4, 7, and 14. To understand how wound healing progressed, the following parameters were calculated:

1. A change in the wound surface area on different days of the experiment $(\triangle S, \%)$ :

$$
\frac{\left(S_{0}-S_{n}\right) \times 100}{S_{0}},
$$

where $S_{0}$ is the initial wound area, $S_{n}$ is the wound area on day $n$. 
2. Relative rate of wound area reduction $\left(v_{\text {heal. }}, \% /\right.$ day):

$$
\frac{\left(S_{0}-S_{n}\right) \times 100 \%}{S_{0} \times n},
$$

where $S_{0}$ is the initial wound area, $S_{n}$ is the wound area on day $\mathrm{n}, \mathrm{n}$ is the day of the experiment.

3. Epithelialization rate $\left(v_{\text {epith. }}, \mathrm{mm}^{2} /\right.$ day $)$ :

$$
\frac{\mathrm{S}_{0}-\mathrm{S}_{\mathrm{n}}}{\mathrm{T}}
$$

where $S_{0}$ is the initial wound area, $S_{n}$ is wound area on day $n, T$ is the number of days between the measurements.

All data were processed in Universlab DeskTer River V3.3.3269

\section{Statistical processing}

We calculated the mean values of the parameters mentioned above and the mean error SEM $=\frac{s}{\sqrt{n}}(s$ is a mean square deviation).

\section{RESULTS}

A day after the animals received PDT, their condition was satisfactory. The animals were active, mucous membranes looked normal and coats were smooth. All wounds were starting to suppurate; the most pronounced suppuration was observed in the controls.

\section{Bacterial contamination}

One of the most important tools used to estimate a therapeutic effect of treatment in patients with soft tissue infection is a microbiological test. We measured the degree of bacterial contamination prior to treatment, and 48, 96 and 168 hours after PDT. The results are presented in Table 2.

Six hours after inoculation but prior to PDT, bacterial burden was the same in all groups: $5.03 \pm 0.04 \times 10^{6} \mathrm{CFU} / \mathrm{ml}$.

Forty-eight hours after PDT the number of $P$. aeruginosa decreased by $10^{2}$ and $10^{3} \mathrm{CFU} / \mathrm{ml}$ in groups C (PDT mediated by the aqueous solution of MC540) and D (PDT mediated by the aqueous solution of MC540 containing $\mathrm{NaCl}$ ), respectively.

\section{Healing progress}

Over the course of monitoring, we established a few differences in the healing dynamics with regard to $\Delta S$ between the animal groups (Table 3).

The $\Delta S$ values in both control groups $A$ and $B$ were significantly lower $(p<0.05)$ than in groups $C$ and $D$ at all stages of the experiment (the only exception was groups $B$ and $\mathrm{C}$ on day 7 when no significant differences were noticed).

Healing rates $\left(v_{\text {neal }}\right)$ turned to be very different within the groups (Table 3). The maximum rate was observed in group $D$, while in other groups $v_{\text {heal }}$ remained quite stable for 14 days $(p>0.05)$. Of note, the healing rates in all groups had slowed by day 14 and almost leveled off.

Epithelization rates $\left(v_{\text {epith }}\right)$ turned out to be significantly different between some groups and within the groups (Table 4).

The highest epithelization rate $\left(v_{\text {epith }}\right)$ between days 4 and 7 was observed in group $D(p<0.05$ in all cases), by day 14 epithelization rates had decreased in all groups.

In the first $48 \mathrm{~h}$ after wound modeling a blood clot was formed in the wound. The major component of the clot was fibrin, which eventually hardened into a scab. The wound produced exudate dominated by neutrophils. Blood cells underwent lysis, manifesting suppurative inflammation (Fig. 1 A).

Table 2. Bacterial contamination of the wound measured on different days of the experiment, CFU/ml

\begin{tabular}{|l|c|c|c|c|}
\hline & \multicolumn{3}{|c|}{ Time after PDT } \\
\hline \multicolumn{1}{|c|}{ Group } & $0 \mathrm{~h}$ & $48 \mathrm{~h}$ & $96 \mathrm{~h}$ \\
\hline Group A & $5.00 \times 10^{6}$ & $1.5 \times 10^{5}$ & $1.7 \times 10^{5}$ \\
\hline Group B & $4.95 \times 10^{6}$ & $1.2 \times 10^{5}$ & $1.6 \times 10^{5}$ & $1.4 \times 10^{4}$ \\
\hline Group C & $5.01 \times 10^{6}$ & $2.0 \times 10^{4}$ & $0.7 \times 10^{2}$ \\
\hline Group D & $5.15 \times 10^{6}$ & $1.5 \times 10^{3}$ & negative & negative \\
\hline
\end{tabular}

\begin{tabular}{|c|c|c|c|c|}
\hline \multicolumn{5}{|c|}{ Changes in the wound surface area throughout the course of the experiment, $\Delta S$} \\
\hline \multirow[b]{2}{*}{ Group } & \multicolumn{4}{|c|}{ Time after PDT } \\
\hline & Day 2 & Day 4 & Day 7 & Day 14 \\
\hline Group A & $11.11 \pm 0.37$ & $25.00 \pm 0.82$ & $41.11 \pm 1.36$ & $84.43 \pm 3.78$ \\
\hline Group B & $13.55 \pm 0.45$ & $32.22 \pm 1.39$ & $50.01 \pm 1.65$ & $85.30 \pm 3.75$ \\
\hline Group C & $16.66 \pm 0.53$ & $40.02 \pm 2.17$ & $48.33 \pm 1.76$ & $93.31 \pm 1.89$ \\
\hline Group D & $30.01 \pm 2.33$ & $55.55 \pm 3.61$ & $67.77 \pm 4.75$ & $94.77 \pm 4.17$ \\
\hline \multicolumn{5}{|c|}{ Relative rate of wound reduction, $v_{\text {heal }}$} \\
\hline & \multicolumn{4}{|c|}{ Time after PDT } \\
\hline Group & Day 2 & Day 4 & Day 7 & Day 14 \\
\hline Group A & $5.55 \pm 0.18$ & $6.25 \pm 0.21$ & $5.87 \pm 0.19$ & $6.03 \pm 0.12$ \\
\hline Group B & $7.50 \pm 0.25$ & $10.51 \pm 0.35$ & $7.14 \pm 0.24$ & $5.95 \pm 0.13$ \\
\hline Group C & $8.33 \pm 0.29$ & $10.00 \pm 0.87$ & $6.90 \pm 0.77$ & $5.92 \pm 0.28$ \\
\hline Group D & $15.01 \pm 0.16$ & $13.88 \pm 1.91$ & $9.68 \pm 1.01$ & $7.33 \pm 0.45$ \\
\hline
\end{tabular}

Table 3. Morphometry of wound matrix remodeling in BALB/c mice 
Beneath the scab immature connective tissue started to grow actively with plenty of thin-walled capillaries, sinuses and lacunae filled with blood (Fig. 1B). On days 4 through 7 the connective tissue underwent fibrosis, transforming in some cases into hyalinized or even calcified scar tissue (Fig 1E). Although such infiltrates are not always deeply seated, they cause contractures and immobilize the skin.

Histological analysis revealed that in the first 24-48 h basal epidermal cells proliferated slowly, and then rapid proliferation took over and keratinization increased. Growing and differentiating, the epidermis gradually closed the wound (Table 4, Fig. E). In general, the wound underwent different stages of healing, which are usually affected by a number of factors, including those set in our experiment (Table 3 and 4, Fig. 1).

Good blood supply, increased oxygenation and a variety of enzymic processes occurring in the wound stimulated tissue substitution and even triggered intracellular regeneration of myosatellite cells (Tables 3 and 4, Fig. 1D).

To sum up, results of the microstructural analysis are consistent with the data obtained in the experiment (Tables
2-4, Fig. 1). Wound healing was exuberant owing to the active growth, differentiation and maturation of the microvasculature, formation of granulation tissue and vigorous epithelization.

\section{DISCUSSION}

In our previous study in vitro we have demonstrated that inactivation of $P$. Aeruginosa occurs ten times more effectively after PDT mediated by the MC540 solution containing $0.25 \mathrm{M}$ sodium chloride than after PDT mediated by the aqueous solution of MC540 [10], which could be explained by the different degree of MC540 aggregation in water and in the presence of salt. In water MC540 exists both as a monomer and a dimer [11], but only monomers can generate reactive oxygen species, specifically singlet oxygen [12, 13]. In saline solutions MC540 forms large crystal-like aggregates capable of producing free radicals [14-17].

The results of the present study conducted in animals convincingly confirm the data obtained in our previous in vitro

Table 4. Rates of epithelial repair of infected wounds in BALB/c mice

\begin{tabular}{|c|c|c|c|c|}
\hline \multicolumn{2}{|c|}{} & \multicolumn{3}{|c|}{ Epithelization rates, $v_{\text {epith }}$} \\
\hline Group & Day 2 & Day 4 after PDT & \multicolumn{2}{c|}{ Day 7} \\
\hline Group A & $1.07 \pm 0.04$ & $5.17 \pm 0.23$ & $15.69 \pm 1.18$ & $16.07 \pm 0.82$ \\
\hline Group B & $2.24 \pm 0.07$ & $6.19 \pm 0.27$ & $14.31 \pm 0.45$ & $6.33 \pm 1.05$ \\
\hline Group C & $2.63 \pm 0.09$ & $5.41 \pm 0.24$ & $6.41 \pm 1.16$ & $6.09 \pm 1.24$ \\
\hline Group D & $3.52 \pm 0.11$ & $8.01 \pm 0.35$ & $8.11 \pm 1.53$ \\
\hline
\end{tabular}

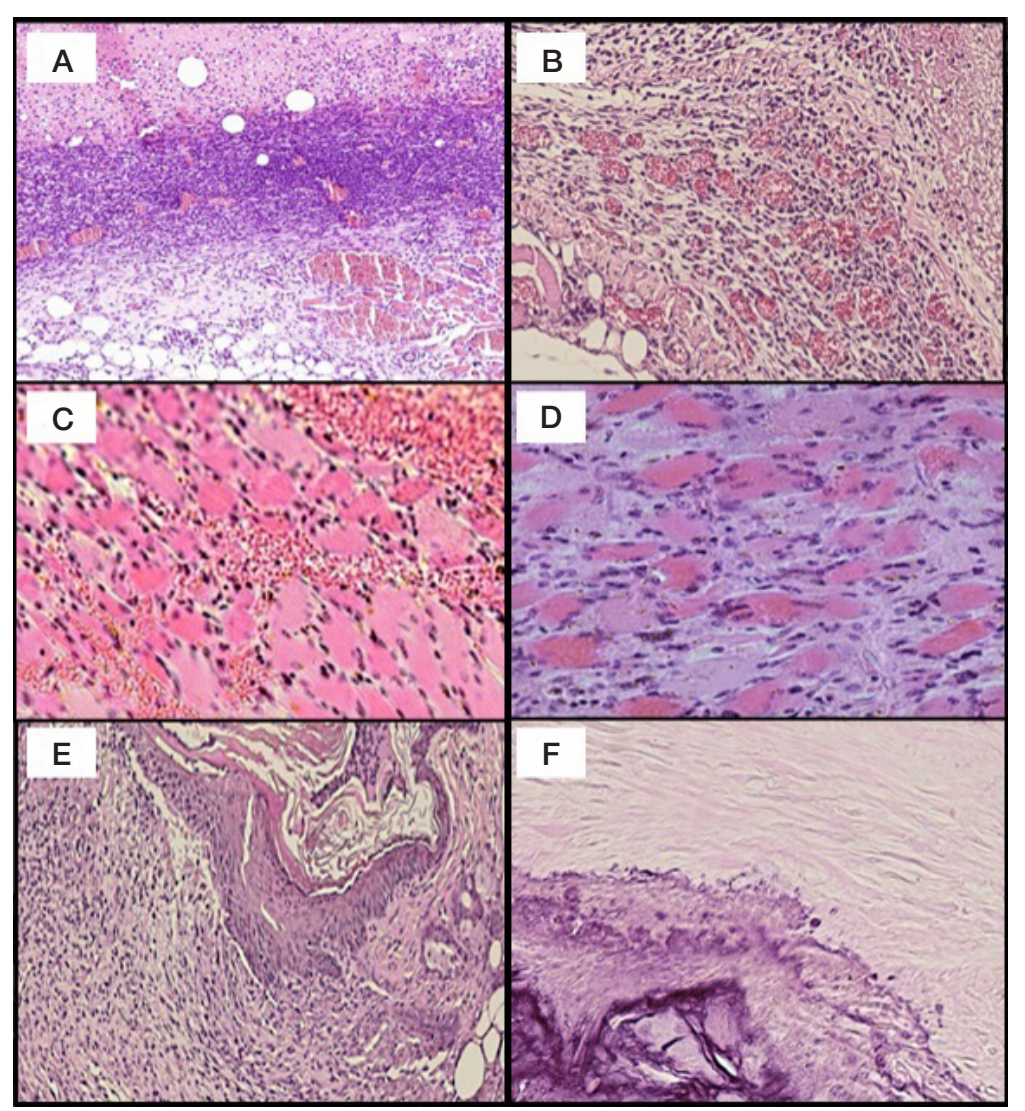

Fig. 1. Microscopy of infected wounds of mice after PDT. Stain used: hematoxylin and eosin (A) Immature granulation tissue on day 4, $\times 150$. (B) Vascular hyperemia and fluid accumulation around the capillary bed on day 4, $\times 350$. (C) Blood in the muscle tissue on day $4, \times 250$. (D) Fragments of muscle tissue showing intracellular cell regeneration of day $7, \times 450$. (E) Epithelialization and scarring on day $14, \times 150$. (F) Hyalinized and calcified scar tissue on day $36, \times 150$ 
work with regard to bacterial death, inhibition and rapid wound healing.

Table 2 shows that after PDT mediated by the MC540 solution containing sodium chloride, full decontamination of the wound infected with multiresistant $P$. aeruginosa is observed as early as on day 4 , while after PDT mediated by the aqueous solution of MC540 it happens on day 7 only.

Morphometry (Table 3) confirms the better effect of MC540 aggregates in comparison with its monomers or dimers with regard to the rate of healing and wound area reduction. By day 4 the wound area in group D shrunk by $45 \%$ whereas in group $\mathrm{C}$ it shrunk by $60 \%$, which is close to the results demonstrated by group B (68\%).

The relative rate of wound healing (Table 3 ) in group A was linear (mean square deviation considered). For groups $B$ and $C$ it was parabolic with a peak on day 4, for group G-exponential. The healing process slowed on day 14 in all groups. These data correlate with the rate of wound area reduction (Table 3).

Regeneration of the epithelium was faster in group $D$ where it became very pronounced on day 4 (Table 4), in comparison with the controls and the group that received PDT mediated by the aqueous solution of MC540.

\section{References}

1. Fakayode OJ, Tsolekile N, Songca SP, Oluwafemi OS. Applications of functionalized nanomaterials in photodynamic therapy. Biophys. 2018; 2. doi: 10.1007/s12551-017-0383-2.

2. Rundle P. Photodynamic Therapy for Eye Cancer. Biomedicines. 2017; 5 (4): 69.

3. Meimandi M, Talebi Ardakani MR, Esmaeil Nejad A, Yousefnejad P, Saebi K, Tayeed MH. The Effect of Photodynamic Therapy in the Treatment of Chronic Periodontitis: A Review of Literature. J Lasers Med Sci. 2017; 8 (1): 7-11.

4. Demidova TN, Hamblin MR. Photodynamic therapy targeted to pathogens. Int J Immunopathol Pharmacol. 2004; 17: 245-54.

5. Hamblin MR, Hasan T. Photodynamic therapy: a new antimicrobial approach to infectious disease? Photochem Photobiol Sci. 2004; 3: 436-50.

6. Hamblin MR. Antimicrobial photodynamic inactivation: a bright new technique to kill resistant microbes. Curr Opin Microbiol. 2016; 33: 67-73.

7. Neundorf I. Reinhardt A. Design and Application of Antimicrobial Peptide Conjugates. Int J Mol Sci. 2016; 17 (5): 701.

8. Joseph B, Janam P, Narayanan S, Anil S. Is Antimicrobial Photodynamic Therapy Effective as an Adjunct to Scaling and Root Planing in Patients with Chronic Periodontitis? A Systematic Review Biomolecules. 2017; 7 (4): 79

9. Liu CC, Zhao JJ, Zhang R1, Li H, Chen B, Zhang LL et al. Multifunctionalization of graphene and graphene oxide for controlled release and targeted delivery of anticancer drugs. Am J Transl Res. 2017; 9 (12): 5197-219.

10. Shmigol TA, Behalo VA, Syisolyatina EV, Nagurskaya EV, Ermolaeva SA, Potapenko AYa. Vliyanie hlorida natriya na

\section{Литература}

1. Fakayode OJ, Tsolekile N, Songca SP, Oluwafemi OS. Applications of functionalized nanomaterials in photodynamic therapy. Biophys. 2018; 2. doi: 10.1007/s12551-017-0383-2.

2. Rundle P. Photodynamic Therapy for Eye Cancer. Biomedicines. 2017; 5 (4): 69.

3. Meimandi M, Talebi Ardakani MR, Esmaeil Nejad A, Yousefnejad P, Saebi K, Tayeed MH. The Effect of Photodynamic Therapy in the Treatment of Chronic Periodontitis: A Review of Literature. J Lasers Med Sci. 2017; 8 (1): 7-11.
Results of the microstructural analysis correlate well with other obtained data (Tables 2-4, Fig.1) indicating rapid wound healing owing to the active growth, differentiation and maturation of the microvascular bed, formation of granulation tissue and vigorous epithelization. But although wound healing and decontamination were faster when PDT was mediated by MC540 in the sodium chloride solution, the healing process was rough, accompanied by fibrin breakdown and fibrinoid formation. PDT mediated by the aqueous solution of MC540 resulted in a slower and not so harsh healing without active fibrinoid formation.

\section{CONCLUSIONS}

The results of our experiment carried out in mice suggest that PDT mediated by the aqueous solution of MC540 containing sodium chloride is more effective against bacterial infection of the modeled wound, inhibits bacterial re-growth and accelerates healing in comparison with the controls and the group that received PDT mediated by the plain aqueous solution of MC540. agregatsiyu merotsianina 540 i fotosensibilizirovannuyu inaktivatsiyu Pseudomonas aeruginosa i Staphylococcus aureus. Acta Naturae. 2011: 112-118.

11. Bilski P, McDevitt T, Chignell CF. Merocyanine 540 solubilized as an ion pair with cationic surfactant in nonpolar solvents: spectral and photochemical properties. Photochem Photobiol. 1999; 69 (6): 671-676.

12. Levard C, Hotze EM, Lowry GV, Brown GE Jr. Environmental transformations of silver nanoparticles: impact on stability and toxicity. Environ Sci Technol. 2012; 3; 46 (13): 6900-14.

13. Kepczynski M, Dzieciuch M, Nowakowska M. Nano-structural hybrid sensitizers for photodynamic therapy. Curr Pharm Des. 2012; 18 (18): 2607-21.

14. Ragàs X, Xin He, Agut M, Roxo-Rosa M, Rocha Gonsalves A Arménio C. Serra et al. Singlet Oxygen in Antimicrobial Photodynamic Therapy: Photosensitizer-Dependent Production and Decay in E. coli. Molecules. 2013; 18 (3): 2712-25.

15. Yin R, Dai T, Avci P, Jorge AE, de Melo WC, Vecchio DH. et al. Light based anti-infectives: ultraviolet $\mathrm{C}$ irradiation, photodynamic therapy, blue light, and beyond. Curr Opin Pharmacol. 2013; 13: 731-62

16. Vatansever F, de Melo WC, Avci P, et al. 2013. Antimicrobial strategies centered around reactive oxygen species - Bactericidal antibiotics, photodynamic therapy, and beyond. FEMS Microbiol Rev. 2013; 37 (6): 955-89.

17. Avci P, Erdem SS, Hamblin MR. Photodynamic Therapy: One Step Ahead with Self-Assembled Nanoparticles J Biomed Nanotechnol. 2014; 10 (9): 1937-52.

4. Demidova TN, Hamblin MR. Photodynamic therapy targeted to pathogens. Int J Immunopathol Pharmacol. 2004; 17: 245-54.

5. Hamblin MR, Hasan T. Photodynamic therapy: a new antimicrobial approach to infectious disease? Photochem Photobiol Sci. 2004; 3: 436-50.

6. Hamblin MR. Antimicrobial photodynamic inactivation: a bright new technique to kill resistant microbes. Curr Opin Microbiol. 2016; 33: 67-73.

7. Neundorf I. Reinhardt A. Design and Application of Antimicrobial 
Peptide Conjugates. Int J Mol Sci. 2016; 17 (5): 701.

8. Joseph B, Janam P, Narayanan S, Anil S. Is Antimicrobial Photodynamic Therapy Effective as an Adjunct to Scaling and Root Planing in Patients with Chronic Periodontitis? A Systematic Review Biomolecules. 2017; 7 (4): 79.

9. Liu CC, Zhao JJ, Zhang R1, Li H, Chen B, Zhang LL et al. Multifunctionalization of graphene and graphene oxide for controlled release and targeted delivery of anticancer drugs. Am J Transl Res. 2017; 9 (12): 5197-219.

10. Шмиголь Т. А., Бехало В. А., Сысолятина Е. В., Нагурская Е. В., Ермолаева С. А., Потапенко А. Я. Влияние хлорида натрия на агрегацию мероцианина 540 и фотосенсибилизированную инактивацию Pseudomonas aeruginosa и Staphylococcus aureus. Acta Naturae. 2011: 112-118.

11. Bilski P, McDevitt T, Chignell CF. Merocyanine 540 solubilized as an ion pair with cationic surfactant in nonpolar solvents: spectral and photochemical properties. Photochem Photobiol. 1999; 69 (6): 671-676.

12. Levard C, Hotze EM, Lowry GV, Brown GE Jr. Environmental transformations of silver nanoparticles: impact on stability and toxicity. Environ Sci Technol. 2012; 3; 46 (13): 6900-14.
13. Kepczynski M, Dzieciuch M, Nowakowska M. Nano-structural hybrid sensitizers for photodynamic therapy. Curr Pharm Des. 2012; 18 (18): 2607-21.

14. Ragàs $X$, Xin He, Agut $M$, Roxo-Rosa $M$, Rocha Gonsalves $A$, Arménio C. Serra et al. Singlet Oxygen in Antimicrobial Photodynamic Therapy: Photosensitizer-Dependent Production and Decay in E. coli. Molecules. 2013; 18 (3): 2712-25.

15. Yin R, Dai T, Avci P, Jorge AE, de Melo WC, Vecchio DH. et al. Light based anti-infectives: ultraviolet $\mathrm{C}$ irradiation, photodynamic therapy, blue light, and beyond. Curr Opin Pharmacol. 2013; 13: 731-62

16. Vatansever F, de Melo WC, Avci P, et al. 2013. Antimicrobial strategies centered around reactive oxygen species - Bactericidal antibiotics, photodynamic therapy, and beyond. FEMS Microbiol Rev. 2013; 37 (6): 955-89.

17. Avci P, Erdem SS, Hamblin MR. Photodynamic Therapy: One Step Ahead with Self-Assembled Nanoparticles J Biomed Nanotechnol. 2014; 10 (9): 1937-52. 